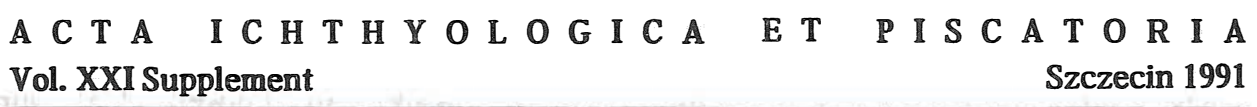

G. ANDRUSHAITIS, V. PLATPIRA

\title{
EFFECTS OF SOME POLYCYCLIC AROMATIC HYDROCARBONS ON THE NATURAL POPULATION OF MARINE BACTERIOPLANKTON
}

\author{
Institute of Biology, Salaspils \\ Latvia
}

\begin{abstract}
Doubling rate, production and the daily $\mathrm{P} / \mathrm{B}$ ratios of natural bacterioplankton populations of the Gulf of Riga were estimated under the impact of $0.001 \mathrm{mg} / \mathrm{dm}^{3}$ anthracene and phenanthrene. In many cases, reduction in the total number of microorganisms was observed, coupled with a decrease in bacterial production. Studies on $24 \mathrm{~h}$ exposure to anthracene and phenanthrene demonstrated toxicity of the hydrocarbon concentrations used to the microbial communities of the Gulf of Riga.
\end{abstract}

\section{INTRODUCTION}

Polycyclic aromatic hydrocarbons $(\mathrm{PAH})$ get into natural waters from oil product processing, waste waters of coking industry, and various accidents (Andelmann and Suess 1970; Boehm 1982; Oudot 1981). Many PAH are carcinogens, their presence in water being hazardous for human health (Daudel and Daudel 1966). Aromatic hydrocarbons are water-soluble; they may accumulate in sediments, their levels there being higher than those in water (Andelmann and Suess 1970). PAH accumulation has been observed in the Baltic Sea (Kirso et al. 1981). Hydrocarbons are typical also of coastal waters (Connell 1982; Hoffmann et al. 1984).

Oils can contain 84-94 $\mu \mathrm{g}$ anthracene/g, while anthracene contents in sediments and in bivalve molluscs are, on the average 3.4 and $0.16 \mu \mathrm{g} / \mathrm{g}$, respectively (Anonymus 1982). If the sediment PAH content is low, benthic organisms accumulate hydrocarbons from the water column as well. On the other hand, if the sediment content is high, the organisms may accumulate PAH from the sediment in the first place (Eadie et al. 1983).

Concurrently with abiotic chemical proceeses, PAH may be photooxidized by microorganisms (various bacteria, fungi, and yeasts). Toxicity of many pollutants has been evaluated using laboratory cultures of aquatic bacteria (Blakemore and Carey 
1978; Calder and Leder 1976; Mahaffey et al. 1982; Walker and Colwell 1975). Our study was aimed at estimating effects of anthracene and phenanthrene on natural bacterial populations in the Gulf of Riga and its coastal areas. At the same time, the microbial reproduction rate and production were assessed.

\section{MATERIALS AND METHODS}

The investigations were carried out at 22 stations in the Gulf of Riga within 13-25 October 1980 . The average water temperature at that time was $10^{\circ} \mathrm{C}$, i.e. a typical seasonal average temperature for the Gulf of Riga. Additionally, samples were collected in coastal areas near Skulte (summer 1983) and Roja (1983-1984).

Bacterial production was evaluated using the generally accepted methods (Gak 1975; Vinberg 1960; Vinberg and Yarovitzina 1946).

To estimate effects of phenanthrene and anthracene on bacterial production, 0.001 $\mathrm{mg} / \mathrm{dm}^{3}$ hydrocarbon solutions were used. The solutions were prepared as in Eganhouse and Calder (1976), and the diurnal bacterial production was analyzed and estimated as in Godlewska-Lipowa (1968).

\section{RESULTS AND DISCUSSION}

Restoration of an ecosystem which has been polluted by hydrocarbons of various structure is closely related to physical, chemical, biological, and geological processes, and depends on the structure of hydrocarbons involved. Biodegradation of hydrocarbons, especially in the northern seas, appears to be ineffective, which can be explained by the fact that only few aquatic organisms can process hydrocarbons in the sea.

Literature data demonstrate that under favourable conditions, an ecosystem can be restored within a year, 10 years being necessary under unfavourable conditions (Butler and Levy 1985).

Studies on the impact of anthracene on bacteria and their development in the Gulf of Riga reveal that the compound hinders reproduction of microbial populations in many areas. While the microbial doubling time ranged within $12-240 \mathrm{~h}$ in the Gulf during the experiment, bacterial decay was observed in the presence of anthracene.

Coastal waters of the Gulf of Riga show variations in their hydrology and hydrochemistry which in turn promote adaptive processes in aquatic organisms. Thus, for instance the bacterial production near Skulte ranged within 0.7-3.3 10 cells $/ \mathrm{ml} \cdot \mathrm{d}$ in summer, the $\mathbb{P} / \mathbb{B}$ ratio being $0.3-1.8$. In those waters, too, the experimental anthracene concentration had a negative effect on the development of bacteria. It resulted in a lower doubling time of the microorganisms and a lower bacterial production, compared with the control. 
PAH degradation in the sea is affected by physical, chemical, and various biological factors, including the type of microorganisms involved, as demonstrated by results obtained off the coast near Roja. Bacterial production in November was particularly affected there, anthracene promoting development of the microflora. In this case, obviously, the bacterial genera Nocardia, Pseudomonas, and Xanthomonas incorporated the compound into their metabolism.

Finally, it should be noted that anthracene is toxic for microorganisms, as demonstrated by Calder and Lader (1976).

Studies on microbial interactions with phenanthrene revealed that the compound adversely affected the microbial communities both in the Gulf of Riga and off the coastal areas near Roja and Skulte. Thus, aquatic microorganisms studied exhibited a low potential activity towards $\mathrm{PAH}$ of various structure. Experiments on phenanthrene biodegradation by microorganisms in the Baltic Sea confirm the finding. No PAH transformation products that could prove degradation of these substances could be identified even using the sensitive chromato-mass-spectrometry (Platpira et al. in press). Previous experiments (Maciejowska 1980) failed to identify microorganisms in the Baltic Sea that could use phenanthrene as a source of carbon and energy.

Degradation of PAH, obvious!y, may be more related to abiotic chemical processes including oxidation, photolysis, and hyrolysis. Thus, $76 \%$ of phenanthrene was degraded in a water body during 4 weeks at $25^{\circ} \mathrm{C}, 45 \%$ of which being due to abiotic chemical processes (Sherill and Sayler 1980).

Biodegradation of anthracene is similarly a very slow process, one which can, obviously, be explained by the nature of hydrocarbon structure (Herbes and Schwall 1978).

Consequently, due to the low PAH biodegradation rate and to the experimentally demonstrated PAH toxicity to microorganisms, the compounds accumulate in sediments, benthic organisms, and fish (Eadie 1982; Grahl-Nielsen et al. 1978; Humason and Gadbois 1982; Kirso et al. 1981). Bioaccumulation is more pronounced in the case of anthracene, compared with other PAH (Bartell and Gardner 1983). Up to $0.35 \mu \mathrm{g}$ anthracene/g accumulated in macrophytes within 60 days, during which time bentic invertebrates and zooplankton accumulated up to 0.23 and $0.04 \mu \mathrm{g} / \mathrm{g}$, respec. tively.

Lee and Singer (1980) reported interesting data on anthracene transformation by Pontoporeia hoyi, although the ability is weak and no hydrocarbon decomposition was observed during a $48 \mathrm{~h}$ exposure. Chironomids can incorporate anthracene into their metabolism (Gerould et al. 1983). Under an increased pollution level in the sea, polychaetes and oligochaetes may participate in decomposition of hydrocarbons. Studies following the "Amoco Cadiz" accident showed that the abundance of molluscs and crustaceans on the bottom and their diversity decreased, while the density of 
oligochaetes and polychaetes sharply increased (Gentil 1983). That is explained by the presence of a multifunctional system of oxygenases in oligochaetes and polychaetes. The enzymatic systems participate in transforming lipophylous organic compounds to soluble substances (Means et al. 1980).

\section{REFERENCES}

Andelmann J.B., M.J. Suess, 1970: Polynuclear aromatic hydrocarbons in the water environment. Bull. WHO, 43: 479-508.

Anonymus, 1982: Cooperative Research Report. 117: 26-30.

Bartell S.M., R.H. Gardner, 1983: Error analysis of predicated fate of anthracene in a simulated pond. Environm. Toxicol. Chem., 2: 29-28.

Blakemore R.P., A.E. Carey, 1978: Effects of polychlorinated biphenyls on growth and respiration of heterotrophic marine bacteria. Appl. Environ. Microbiol., 35: 329-336.

Boehm P.D., 1982: Chemical investigations on the transport and fate of petroleum hydrocarbons in littoral and benthic environments: The Tzesis oil spill. Mar. Environ. Res., 6: 57-70.

Butler J.N., E.M. Levy, 1985: Long-term fate of petroleum hydrocarbons after spills. Compositional changes and microbial degradation. J. Fish. Res. Bd Can., 35: 604-605.

Calder J.A., J.H. Lader, 1976: Effect of dissolved aromatic hydrocarbons on the growth of marine bacteria in batch culture. Appl. Environ. Microbiol., 32: 95-101.

Connell D.W., 1982: An approximate petroleum hydrocarbon budget for the Hudson Raritan Estuary, New York. Mar. Poll. Bull., 13: 89-93.

Daudel P., R. Daudel, 1966: Chemical carcinogenesis and molecular biology. Wiley Interscience: $34-35$.

Eadie B.J., 1982: Polycyclic aromatichydrocarbons in sediments, pure water and the amphipod Pontoporeio hoyi from Lake Michigan. Chemosphere, 2: 847-858.

Eadie B.J., W.R. Faust, P.F. Landrum, 1983: Bioconcentrations of PAH by some benthic organisms of the Great Lakes. In: Polynuclear aromatic hydrocarbons. Formation, metabolism and measuring. Proc. 7th intern. Symp. Columbus. Richland: 437-479.

Eganhouse R.P., J.A. Calder, 1976: The solubility of medium molecular weight hydrocarbons and the effects of hydrocarbons cosolates and salinity. Geochim. Cosmochim. Acta, 40: 555-561.

Gak D.Z., 1975: Teoreticheskye osnovy pramogo metoda opredelenya produkcii bakteriy. In: Bakteryoplankton i ego rol v biologicheskoy produktivnosti vodokhranilishtch. Nauka, Moskva.

Gentil E., 1983: Description du benthos de l'Aber Wrac (Nord Bretagne) et impact a court terme des hydrocarboures de l' "Amoco Cadiz". In: C.R.107-e Congr. Nat. Soc. Savantes. Brest. 2: 111-125.

Gerould S., P. Landrum, J. Giesy, 1983: Anthracene bioconcentration and biotransformation in chironomids: effects of temperature and concentration. Environm. Poll., 30A: 175-188.

Godlewska-Lipowa W., 1968: Relationship between the generation time of a group of bacteria in water and the exposure time and capacity of flasks. Bull. Acad. Polon. Sci. Ser. Biol., 17: 233-237.

Grahl-Nielsen O., J.T. Staveland, S. Wilhelmsen, 1978: Aromatic hydrocarbons in benthic organisms from coastal areas polluted by Iranian crude oil. J. Fish. Res. Bd. Can., 35: 615-623.

Herbes S.E., I.R. Schwall, 1978: Microbial transformation of polycyclic aromatic hydrocarbons in pristine and petroleum contaminated sediments. Appl. Environm. Microbioll., 35: 306-312.

Hoffmann E.J., G.L. Mills, J.S. Latimer, 1984: Urban runoff as a source of polycyclic aromatic hydrocarbons to coastal waters. Environ. Sci. Technol., 18: 580-587.

Humason A.W., D.F. Gadbois, 1982: Determination of polynuclear aromatic hydrocarbons in the New York Bight area. Bull. Environm. Contam. Toxicol., 29: 645-650.

,Kirso U., E. Urbas, K. Kuiv, 1981: Polycyclic arenes in the Baltic waters. Izv. AN Est. SSR, 30: 219-223. 
Lee R.F., S.C. Singer, 1980: Detoxifying enzymes system in marine polychaetes: increases in activity after exposure to aromatic hydrocarbons. Rapp. Proc.-verb. Reun. Cons. int. Explor. Mer, 179: 29-32.

Maciejowsłka M., 1980: Mikroorganizmy rozkładające węglowodory w środowisku morskim. Inst. Kształ. Środ. Warszawa, $139 \mathrm{pp}$.

Mahaffey W.R., P.H. Priotchard, A.W. Bourgin, 1982: Effects of Kepone on growth and respiration of several estuarine bacteria. Appl. Environ. Microbiol., 43: 1419-1424.

Means J.C., S.G. Wood, J.J. Hasset, 1980: Sorption of polynuclear aromatic hydrocarbons by sediments and soils. Environm. Sci. Technol., 14: 1524-1529.

Oudot J., 1981: Hydrocarbon weathering in seashore invertebrates and sediments over a two-year period following the Amoco Cadiz oil spill: influence of microbial metabolism. Environm. Poll., 26A: 93-100.

Platpira V.P., G.P. Andrushaitis, A.T. Lebeder, V.S. Petrosyan (in press): Eksperimentalnye issledovanya biodestukcii fenantrena v Baltijskom more. Issled. Mir. Okeana, Moskva.

Sherill T.W., G.S. Sayler, 1980: Phenanthrene biodegradation in freshwater environments. Appl. Environm. Microbiol., 39: 172-174.

Vinberg G.G., 1960: Pervichnaya produkcya vodoemov. Izdat. AN BSSR Minsk, 328 pp.

Vinberg G.G., L.I. Yarovitzina, 1946: Razmnozhenye bakteryi i pogloshchenye kisloroda v vode. Mikrobiolo, 15: 499-508.

Walker J.D., R.R. Colwell, 1975: Some effects of petroleum on estuarine and marine microorganisms. Can. J. Microbiol., 21: 305-313.

Authors' address:

Institute of Biology

Latvian Academy of Sciences

Salaspils

Latvia 